\title{
Student Mentoring in the Master Programme "Pedagogy": the case of University of Latvia
}

\author{
Dita Nimante, Sanita Baranova
}

Faculty of Pedagogy, Psychology and Art, University of Latvia, Latvia.

\begin{abstract}
There is a developing interest in mentoring and tutoring in the higher education in Latvia. Mentoring is looked at as a retention strategy to support students to remain and continue studies and as a tool to prevent students' drop out from the university. Since academic year 2016/2017 several programmes of tutoring and mentoring in basic studies (bachelor level studies) have been developed and financially supported at the University of Latvia, but so far mentoring has not been used for Master level students. The Master program "Pedagogy" includes a theoretical course "Methods of Mentoring at the Educational Institution”. Since academic year 2018/2019 new tasks were introduced for the second year Master students to become peer mentors for the first year students, thus, integrating their theoretical knowledge into the practice, making a closer connection to the $1^{\text {st }}$ year students, by sharing their Master student experience. Data were collected (reflection, portfolios, focus group discussion) both from (14) the $1^{\text {st }}$ year Master students and (14) $2^{\text {nd }}$ year Master students at the end of the course and were analysed qualitatively to reveal the results of peer mentoring experience. The results suggest that both the mentors and the mentees benefited from their involvement in mentoring. The research presents some new benefits and challenges for the professional development of academic staff and student-centred learning in the Master level programme.
\end{abstract}

Keywords: Peer mentoring, Student-centred learning, Reflection, Quality ensuring. 


\section{Introduction}

In Latvia the rate of students who drop out of the higher education institutions and colleges is rather high. In the academic year 2017/2018, 81.6 thousand students entered 54 higher education institutions - 29 higher education institutions and 25 colleges in Latvia, but the number of students decreased by 43.8 thousand or 35 \% (Latvia. Statistics in brief 2018). Student withdrawal remains a concern across higher education sectors world wide for the last few decades (Fourie, 2018, Harvey, Szalkowicz, 2017, Fortin, Sauvé, et.al. 2016). It concerns different programmes and students of different age (Fortin, Sauvé, et.al., 2016, Silver, Jakeman, 2014). As a result researchers and higher education practitioners are looking for ways to support students during their study process. Several strategies can be used for that and they are described in literature. Mentoring, especially peer mentoring, is looked at as a retention strategy to support students to remain and continue their studies and as a tool to prevent students' drop out from the university.

The first part of the paper provides a brief outline of the relevant literature, the second part explains the mentoring experience at the University of Latvia and how the theoretical course "Methods of Mentoring at the Educational Institution" in the Master programme "Pedagogy" was developed to insure the support mechanism for the $1^{\text {st }}$ year Master programme students using peer mentoring. The third part will elaborate on the gathered data. The qualitative analysis reveals the results of the mentoring experience both on the part of the $1^{\text {st }}$ year students and $2^{\text {nd }}$ year students. Finally, there are some conclusions drawn. The paper seeks to answer the question: what are the benefits from the involvement in peer mentoring in Master level programme for both sides - mentors and mentees and what are the challenges?

\section{Theoretical background}

Factors that can influence the students' decision to leave studies have been determined as those that can be and can not be directly influenced by institutions. Relatively few research on Master level students mention both socio-economic, for example, financial concerns, the distance from the university, student affairs as devalued work, and personal, for example, lack of fulfillment and emotional burdens (Silver, Jakeman, 2014). Perry, Boman et al. (2008) argue that the major reasons for leaving the universities can be placed into two categories, personal reasons and programme reasons. The personal reasons include different life circumstances, work commitments, the programme reasons include the learning style, evolving career aspirations (Perry, Boman et al., 2008). As suggested by Willcoxson, Cotter et al. (2011), the programme reasons concern more students in later years, as withdrawals may be influenced by the quality of interactions with the academic and administrative staff, feedback processes, teaching quality, course advice and university policies and facilities (Willcoxson, Cotter, et al., 2011). 
With a better understanding of these factors, it has become possible to choose the specific strategies to reduce the number of leaving students from universities much more purposefully. There are several strategies proposed: related to the course design, course delivery, and programme organisation; there are strategies for the re-integration of students who have withdrawn and subsequently decide to return to studies (Park, Perry, et al., 2011) or for those who are at risk for withdrawing (Harvey, Szalkowicz, 2017). Mentoring and peer mentoring in higher education is consider as one of the cost effective strategies to enhance personal and professional growth among students and to prevent student dropout (Fox, Stevenson, 2006, Terrion, Leonard, 2007). Alongside with the social support (Heirdsfield, Walker, et al., 2008) it provides the psychological and emotional support to mentees (Gunn, Lee, et al., 2016). Mentoring programmes help students to acquire a specific skill for the academic success. It can lead to a greater satisfaction with time allocation at work, higher academic self-efficacy (Feldman, Arean, et.al., 2010). The empirical results suggest that mentoring has a positive effect on the academic performance of mentees (Fox, Stevenson, 2006). The result of such programmes is that both mentors and mentees benefit significantly from their involvement in mentoring. According to Kram (1983) this relationship has the potential to enhance career development and psyhosocial development of both individuals. Terrion and Leonard (2007), enhanced Kram's (1983) mentoring model, by developing a taxonomy of five prerequisites for the student peer mentor, two student peer mentor characteristics that support the career-related function and eight characteristics that support the psychosocial function (Terrion, Leonard, 2007). Later research has indicated psychosocial assistance, networking help, and relational outcomes as an important outcome reported most among participants after participating in a peer mentoring programme (Fleck, Mullins, 2012). Despite benefits reported by many previous studies, peer mentoring can have some challenges too, sometimes it is a far from the perfectly harmonious process between mentors and mentees (Lim, MacLeod, et al., 2017) and it can bring some frustration of mentors (Heirdsfield, Walker, et al., 2008). Therefore, as it is stressed by Terrion and Leonard (2007), there are some prerequisites for the student peer mentoring: the ability and willingness to commit time, gender and race maching, the same university experience, the academic achievement of the mentor, prior mentee experience (Terrion, Leonard, 2007). However, the findings differ on how important it is to prepare mentors prior to mentoring. There is research suggesting that it is not such an essential mentor program characterisctic (Fleck, Mullins, 2012), at the same time other research insists that preparation or induction for mentoring is an important part of successful mentoring (Heirdsfield, Walker, et al., 2008). Findings of Gunn, Lee, et.al. (2017) have concluded that potential peer mentors should participate in structured orientation sessions, so that mentors would feel comfortable with (a) assisting mentees with academic, social, and personal challenges, (b) role modelling, (c) sharing academic and social experiences and challenges, (d) connecting mentees to campus 
resources, and (e) helping mentees develop academic skills in order to be more successful at the university level (Gunn, Lee, et al., 2017, 23).

\section{Empirical study}

\subsection{Mentoring experience at the University of Latvia}

Since academic year 2016/2017 several programmes of tutoring and mentoring in basic studies (bachelor level studies) have been developed and financially supported at the University of Latvia. University of Latvia applies several actions according to "The Standards and Guidelines for Quality Assurance in the European Higher Education Area” (2015) to support all phases of the student "life cycle" from student admission, development and graduation. Up to now mentoring has not been used for Master level students. The Master programme "Pedagogy" includes a theoretical course "Methods of Mentoring at the Educational Institution”. Until this year it was taught to $2^{\text {nd }}$ year students and the course was mostly related to developing students' understanding of the essence of mentors' activities, their functioning in different educational settings, especially mentors for novice teachers in schools. Since academic year 2018/2019 new tasks were introduced for 14 second year Master students to become mentors for 14 first year students, thus integrating their theoretical knowledge into the practice, making closer connection to the 1st year students, by sharing their master student experience. Only a part of the Master programme students has studied previously at the University of Latvia on their bachelor level; the majority have their bachelor education in pedagogy, the rest - in other branches of science (e.g., philology, art, politology, economics, history, theology). All students are employed. Six student families in the $2^{\text {nd }}$ year and seven families in the $1^{\text {st }}$ year have preschool and/or school age children.

During the first two autumn semester months (September - October) in the frame of the course $2^{\text {nd }}$ year students acquired theoretically the basics of mentoring, chose the $1^{\text {st }}$ year student for mentoring, found out the needs of the mentee, developed the action plan of mentoring and started the mentoring of the $1^{\text {st }}$ year students. It was the first experience for the majority of students. Two of the $2^{\text {nd }}$ year Master programme students had already had some prior experience.

\subsection{Data collection and results}

Firstly, peer mentoring data have been collected by distributing self-report surveys and, secondly, facilitating a focus group disscussion. Data obtained during the research were analysed qualitatively to reveal the results of the peer mentoring experience. Responses were analysed according to the principles of thematic analysis, first dividing the units of the content of the answers, then grouping them into sub-topics and closing the categories at the end. 
Results revealed four aspects that caused different challenges to both mentors and mentees the physical environment of the faculty; the experience of students' previous education; students' employment and the family status. The faculty changed its location in academic year 2018/2019, thus, in general the physical environment of the faculty was unknown to both the mentors and mentees.

There were some attitude problems at the beginning from mentors side. Initially, two of the $2^{\text {nd }}$ year students coming from another higher education institution had a rather sceptical attitude to their role as the mentor of the $1^{\text {st }}$ year students. One of them wrote: "I feel mentoring as a partly imposed activity that creates unnecessary stress, opposition." The other, in her turn, wrote: "My mentee is knowledgeable, also confident, sure of her abilities; she is able to cope herself with everything. I can't imagine how I can be of help to her." Both these mentors also pointed out that they had studied at another university. Yet, the mentors' doubts diminished as soon as they got acquainted with their mentees and had explored their needs. One mentor writes: "At the beginning I was worried when the mentee announced that she did not see any point in all this. However, reading the needs questionnaire filled by this student I understood that it would be useful for her to find out the academic staff of the Master programme, the available resources, e-studies, the writing of the Master's paper."

Most of mentors even at the initial stage of mentoring are aware that there are several benefits in the mentor's work; it also gives possibilities for acquiring additional skills. This aspect that mentoring serves as a possibility for gaining valuable experience for both sides has been also stressed by mentees. A mentor writes: "Although the mentee's needs and development is in the centre, both should be winners." Other mentors, too, indicate that they will need "responsibility, leadership skills, the willingness to help in their mentoring of the $1^{\text {st }}$ year students". Common professional and research interests that encourage both the sides to mutual exchange of experience are significant in the initial cooperation of the mentor and the mentee.

From the mentees side, at first, mentees expect the mentor to be responsive, to help to solve issues related to university life, to share the personal experience: "To my mind, if the person tells something from her personal experience, it creates the sense of safety and the conviction that I also can do it."

The analysis of the results of the focus group discussion allowed concluding that no contradicitions were found in the answers given by mentors and mentees. The most important benefit from the implemented mentoring has been the consultative support provided by mentors regarding the programme - the choice of the research theme, facilitation of a better understanding of the content and organization of the studies. The mentor's support has been especially important for those students who had not previously studied at the University of Latvia when getting familiar with the e-learning system as well as students who had not 
studied pedagogy before. The obstacles in the face-to-face communication mentioned both by the mentors and mentees have been being busy at work and difficulties in finding common time for cooperation.

Mentors admitted in the focus group discussion that they themselves as mentors had had to learn much, to acquire both the knowledge and skills. Two mentors emphasized especially that in case of uncertainy they had had to search for information reading articles about the mentoring experience of other mentors. Mentors had observed the behaviour of other people, have mastered the skill to listen, to provide the feedback, to reflect on what they had seen and heard. Mentors had understood that the key skills in mentoring were the skill to set the boundaries, confidentiality, "not intruding" too much with their help as well as it was important for the mentors to be aware of their own emotional resources and personal competence. According to mentees, their biggest challenges had been the lack of selfdiscipline and the skill of planning their time.

Both mentors and mentees pointed to the emotional support that they had given or received. Mentors stressed that the fact that you had been in a similar situation as the mentee had helped in mentoring.

Mentors also concluded that mentees were mainly suppressed by everyday things, issues at their work, care for the family while the issues related to the studies had mainly been easily understandable, easily solved. Mentees had found the advice, concerning requirements that had to be observed studying with each lecturer of the programme, useful.

All in all, the implemented mentoring can be assessed as a positive experience for all those involved who continue studying in this programme. However, during the programme two $1^{\text {st }}$ year students did not pass the examinations of the first semester and did not continue their studies due to reasons that were not connected with the university. Yet, owing to the mentoring programme, it is known why they dropped out from their studies and that the reason can not be directly influenced by the higher education institution: one of the students cannot combine studies with the load at work and the necessity of choose work as the priority to provide financially for oneself; the other student discontinued studying due to her children's prolonged illness.

\section{Conclusion}

The mentoring relationship can lead to different outcomes because of its multifaceted nature. This research provides insights into mentors and mentees' experiences in the Master programme "Pedagogy" during the course "Methods of Mentoring at the Educational Institution”. The introduction of peer - mentoring in the Master programme does not allow fully avoiding the student drop out, where the reasons are not directly connected to and 
influenced by the educational institution, but it is better understood thanks to mentoring. However, mentoring provides support in the acquisition of the programme and in coping with different personal aspects. During mentoring mentors and mentees experienced several benefits, both related to the programme and personal aspects, such as the given consultative support in relation to the programme and research - the choice of the research theme, facilitation of a better understanding of the content and organization of the studies. Mentors admitted that they hadmastered leadership skills while mentees, in their turn, acknowledged that they had gained socioemotional support. It coincides with Heirdsfield, Walker, et al. (2008). It is especially important for those students who had studied in another higher education institution or faculty before, or had received their bachelor degree several years ago, or had studied in other than pedagogy programmes. Mentors experienced several challenges throughout the mentoring experience: the physical environment of the faculty; the experience of students' previous education; students' employment and the family status.

Overall, the positive experience suggest, that the mentoring should be continued and probably made an institution-wide approach (Nelson, Smith, Clarke, 2012) not only for the experience of the $1^{\text {st }}$ year students, but for the Master programme students, too.

\section{References}

Fortin, A., Sauvé, L., Viger, C., Landry, F. (2016). Nontraditional student withdrawal from undergraduate accounting programmes: a holistic perspective. Accounting Education. 25(5). 437-478. doi: https://datubazes.lanet.lv:4876/10.1080/09639284.2016.1193034

Fourie, C. M. (2018) Risk factors associated with first-year students'intention to drop out from a university in South Africa. Journal of Further and Higher Education. doi: https://datubazes.lanet.lv:4876/10.1080/0309877X.2018.1527023.

Fox, A., Stevenson, L. (2006). Exploring the effectiveness of peer mentoring of accounting and finance students in higher education. Accounting Education, 15(2), 189-202. doi: https://datubazes.lanet.lv:4876/10.1080/06939280600595145

Fleck, C., Mullins, M.E. (2012) Evaluating a Psychology Graduate Student Peer Mentoring Program. Mentoring \& Tutoring: Partnership in Learning. 20(2), 271-290. doi: https://datubazes.lanet.lv:4876/10.1080/13611267.2012.687157

Gunn, F., Lee, S. H. (M.), Steed, M. (2017) Student Perceptions of Benefits and Challenges of Peer Mentoring Programs: Divergent Perspectives From Mentors and Mentees. Marketing Education Review, 27(1), 15-26. doi: https://datubazes.lanet.lv:4876/10.1080/10528008.2016.1255560

Harvey, A., Szalkowicz, G. (2017). From departure to arrival: Re-engaging students who have withdrawn from university. Journal of Further and Higher Education, 41(1), 79-97. doi: https://datubazes.lanet.lv:4876/10.1080/0309877X.2015.1062852)

Heirdsfield, A. M., Walker S., Walsh, K., \& Wilss, L., (2008). Peer mentoring for first-year teacher education students: the mentors' experience. Mentoring \& Tutoring: Partnership 
in Learning, 16(2), 109-124. doi: https://datubazes.lanet.lv:4876/10.1080/13611260801916135

Kram, K.E. (1983). Phases of the mentor relationship. Academy of Management Journal, 26, 608-625. doi: https://www.zdruzenje-manager.si/assets/Baza-znanja/Razvoj-zenskegamanagementa/Phases-of-the-Mentor-Relationship.pdf

Latvia. Statistics in brief (2018) Central statistical bureau of Latvia. doi: https://www.csb.gov.lv/sites/default/files/publication/2018-

05/Nr\%2003\%20Latvia_Statistics\%20in\%20Brief\%202018\%20\%2818_00\%29\%20EN. pdf)

Lim J. H., MacLeod, B. P., Tkacik, P. T., Dika S. L. (2017). Peer mentoring in engineering: (un)shared experience of undergraduate peer mentors and mentees. Mentoring \& Tutoring: Partnership in Learning, 25(4), 395-416. doi: https://datubazes.lanet.lv:4876/10.1080/13611267.2017.1403628

Feldman, M. D., Arean, P. A., Marshall, S. J., Lovett, M., O'Sullivan, P. (2010). Does mentoring matter: results from a survey of faculty mentees at a large health sciences university. Medical Education Online, 15 (1). doi: https://datubazes.lanet.lv:4876/10.3402/meo.v15i0.5063

Nelson , K. J. Smith, J. E., Clarke, J. A. (2012). Enhancing the transition of commencing students into university: an institution-wide approach. Higher Education Research \& Development, 31(2), 185-199. doi: https://datubazes.lanet.lv:4876/10.1080/07294360.2011.556108

Park, C. L., Perry, B., Edwards, M. (2011). Minimising attrition: strategies for assisting students who are at risk of withdrawal. Journal Innovations in Education and Teaching International, 48(1), 37-47. doi: https://datubazes.lanet.lv:4876/10.1080/14703297.2010.543769

Perry, B., Boman, J., Care, W.D., Edwards, M., Park, C. (2008). Why do students withdraw from online graduate nursing and health studies education: A descriptive study. Journal of Educators Online, 5(1): 1-17. doi: https://files.eric.ed.gov/fulltext/EJ904043.pdf

Silver, B. R., Jakeman, R. C. (2014). Understanding Intent to Leave the Field: A Study of Student Affairs Master's Students' Career Plans. Journal Journal of Student Affairs Research and Practice. 51(2), 170-182. doi: https://datubazes.lanet.lv:4876/10.1515/jsarp-2014-0017

Standards and Guidelines for Quality Assurance in the European Higher Education Area (ESG). (2015). Brussels, Belgium.

Terrion, J. L., Leonard, D. (2007). A taxonomy of the characteristics of student peer mentors in higher education: findings from a literature review. Mentoring \& Tutoring: Partnership in Learning, 15(20), 149-164. doi: https://datubazes.lanet.lv:4876/10.1080/13611260601086311.

Willcoxson, L., Cotter, J., Jo, S. (2011). Beyond the first-year experience: the impact on attrition of student experiences throughout undergraduate degree studies in six diverse universities. Studies in Higher Education, 36(3), 331-352. doi: https://datubazes.lanet.lv:4876/10.1080/03075070903581533 